\title{
Fazendo América em Niterói: Prestamistas e comerciantes judeus na capital fluminense
}

\author{
Andréa Telo da Corte \\ Museu de História e Artes do Estado do Rio de Janeiro
}

A capital fluminense conheceu nas primeiras décadas do século XX, uma lenta evolução urbana em comparação à velocidade das transformaçôes vividas pelo Rio de Janeiro na Era Pereira Passos, o que pôs Niterói na contramão da modernidade.

$\mathrm{Na}$ década de1920, sob a gestão do então presidente de estado, Feliciano Sodré (1923-1927) um primeiro conjunto de intervenções no espaço público resultou no desenvolvimento do comércio, indústrias, vilas operárias, bancos, colégios, cinemas, e áreas de lazer, que contribuíram para a intensificação da vida urbana na cidade.

Posteriormente, com a passagem de Ernani do Amaral Peixoto pela Interventoria durante o Estado Novo (1937-1945) e, mais tarde, pelo governo do Estado do Rio de Janeiro (1951-55), outro importante conjunto de reformas urbanas foi implementado, corroborando para a que a cidade adquirisse simbolicamente o status necessário para abrigar a sede da capital estadual, além de ganhar importância no cenário nacional.

Foi nesse contexto que imigrantes judeus de diversas nacionalidades, oriundos em sua maioria do vasto império russo, radicaram-se na cidade onde efetuaram um processo particular de territorialização, no sentido específico da dominação política e econômica e de apropriação cultural e simbólica do espaço local. ${ }^{1}$

Seja como prestamistas ou lojistas, e muitas vezes atuando nas duas frentes, foi por intermédio do comércio e de um conjunto diversificado de associações culturais e religiosas que os judeus de Niterói impriram suas marcas no espaço da cidade. No que se refere ao quadro econômico local, constituíram, entre 1910-1970, um lugar particular no mercado de móveis, tecidos, jóias, relógios e roupas prontas da capital fluminense. 
O esforço das associações comunitárias judaicas locais - Centro Israelita de Niterói, a Associação Davi Frischman de Cultura e Recreação e a Sociedade Hebraica de Niterói - em fixar a história dos judeus na cidade e rememorar sua experiência, foi responsável pela ação de enquadrar a memória grupal através de uma narrativa isenta de problemas, clivagens e contradições, ou seja, pela elaboração de uma memória perfeita sobre a trajetória dos judeus na capital fluminense. Exemplo disso é o texto preparado por Samuel Baron e Gerson Kotchmar intitulado Histórico da Comunidade Israelita de Niterói, de dezembro de 1994.

De acordo com os autores, a coletividade judaica de Niterói teve início com a chegada de judeus russos à cidade por volta do ano de 1910. Tratavam-se em sua maioria de mascates elou prestamistas, que "com a melhoria do nível de ganhos, /.../ conseguiu abrir lojas comerciais no centro da cidade, onde comerciavam tecidos, roupas móveis, etc". Já a geração seguinte "dedicou-se às profissōes liberais, aí começando sua mudança para a cidade do Rio de Janeiro, centro maior, onde eram maiores as oportunidades de trabalho e lazer". ${ }^{2}$

Além deste documento interno redigido por nomes expressivos da coletividade, uma série de entrevistas de remanescentes do grupo situou o comércio lojista no decorrer das décadas de 1940, 1950 e 1960, assim como interpretou a atividade de prestamista como uma etapa da ascensão social dos comerciantes. Portanto, na narrativa que construíram para si, as lojas aparecem como conseqüência natural do capital acumulado no trabalho nas ruas, como clienteltchik. ${ }^{3}$ A continuidade desse ofício, entretanto, era quase sempre vista como fracasso.

Ultrapassar, portanto, a barreira da memória constituída pela comunidade para compreender as formas de dominação econômica e apropriação simbólica do espaço pelo grupo na primeira geração, isto é, pelos pioneiros é o objetivo deste artigo. ${ }^{4}$ Os marcos entre 1910-1970, justificam-se por corresponder respectivamente à formação e transformação da comunidade judaica de Niterói.

\section{Prestamistas e Comerciantes}

De acordo com o Almanak Laemmert, entre 1910-1940, 59 comerciantes judeus já estavam estabelecidos na cidade de Niterói, perfazendo um total de 69 lojas, realidade nova para o próprio grupo, que acreditava que a abertura de casas comerciais fosse um dado posterior à década de 1940.5 
$\mathrm{Na}$ verdade, boa parte dos nomes encontrados havia sido esquecida pelos remanescentes. Outros, abandonaram a capital fluminense antes dos anos quarenta. De modo que a realidade descortinada pela pesquisa surpreendeu a coletividade. As fontes compulsadas apontaram ainda um quantitativo de 180 lojistas para o período de $1910-1970 .^{6}$

No que se refere aos clienteltchik outra surpresa: a consulta ao livro da União dos Ambulantes de Niterói (UBAN) associação de vida curta e que havia sido esquecida pelo grupo, registrou entre 29 de dezembro de 1940 e 3 de novembro de 1941, sessenta e nove matrículas. Assim como no caso dos lojistas, por motivos vários, nem todos os prestamistas em atividade na época devem ter se filiado à referida associação. É provável, pois, que houvesse um número maior desses trabalhadores atuando no período.

A pesquisa sobre o número de lojistas e clienteltchik na cidade foi completada pelas fontes orais ${ }^{7}$, a partir do que foi possível elaborar, em um quadro indicativo dos ambulantes para o período entre 1930-1970, sendo impossível retroceder a 1910, como no caso dos lojistas. No computo final chegamos ao quantitativo de 140 prestamistas para o período assinalado. Deste pudemos constatar que apenas $\underline{24}$ transferiram-se ao longo do tempo para o comércio lojista, reduzindo o total para 116.

A coletividade judaica de Niterói, entre lojistas e prestamistas, totalizou um número próximo a $296(180+116)$ comerciantes. A estes devem ser acrescentados ainda, um funcionário público, um artesão, três profissionais liberais, alcançando a soma final de 301 sujeitos identificados. Outras 14 pessoas apesar de terem seus nomes registrados nas fontes não foram identificadas pelo conjunto de depoentes, não se sabendo ao certo quem eram, e o que faziam, sendo possível que sua estada na cidade tenha sido rápida.

Importa dizer que não existem informações substantivas sobre a população judaica em Niterói. Dados coletados na Sinopse Estatística do Município de Niterói referentes a 1940 e corrigidos em 1951, informaram a presença de 9.740 estrangeiros, dos quais 6292 eram portugueses, 669 italianos, 676 alemães, 472 espanhóis, 19 japoneses, e ainda 23 sujeitos sem nacionalidade identificada. A soma desses números alcança a casa de 8.111 imigrantes, restando, portanto, 1629 pessoas sem qualquer indicação de origem, para um quantitativo populacional geral de 131.687 habitantes.

É dentro desses 1629 que vamos encontrar o total de judeus da cidade no decênio 1940-1950. Embora os dados obtidos sobre prestamistas e 
lojistas permitam fazer uma projeção quantitativa da comunidade para 1940, usaremos as informaçôes coletadas em outro documento: a lista dos contribuintes da Campanha de Emergência em prol do Estado de Israel, promovido pela Organização Sionista Unificado do Brasil do ano de 1948.

Nele foram listados 216 colaboradores chefes de família em Niterói, a maior parte homens. Se multiplicarmos cada um deles por um número padrão de cinco pessoas por família chegaremos a um total de 1080 judeus na cidade. Como os números publicados na Sinopse foram corrigidos em 1951, podemos realmente vislumbrar em parte das 1629 pessoas sem qualquer indicação de nacionalidade, os judeus de Niterói.

Esse número, claro, é uma hipótese, uma vez que as famílias da época eram, muitas vezes, maiores, abrigando também outros familiares e amigos que não temos como identificar. Sabemos também que cálculos demográficos são mais complexos do que o quadro apresentado, mas de toda forma os números encontrados captam uma tendência, servindo, portanto, para balizar o estudo proposto.

$\mathrm{Na}$ falta de outros referenciais somente é possível comparar esses números com os recolhidos por Jeffrey Lesser para a população judaica no Estado do Rio de Janeiro no censo de 1950, que aponta um total de 25.222 judeus residentes no Distrito Federal e 2.209 no Estado do Rio de Janeiro. ${ }^{8}$ Dada a projeção da capital do estado, é perfeitamente possível aceitar os números acima estimados, e projetar o quantitativo geral de judeus em Niterói para o decênio de 1940, para algo em torno de 1080 indivíduos.

Quanto à questão da nacionalidade, tomando como base exclusivamente os 116 prestamistas e os 180 lojistas foi possível apreender que entre russos $(14,1 \%)$, poloneses $(34,4 \%)$, e romenos $(19,5 \%), 68 \%$ desses imigrantes eram oriundos de regióes que pertenceram à Rússia czarista, o que pode explicar a idéia generalizada na comunidade de uma maioria de judeus russos na cidade. ${ }^{9} \mathrm{Na}$ verdade, é a presença maciça de poloneses que chama a atenção. Finalmente, os números perfazem uma maioria de 97\% judeus asquenaze, e 3\% sefaraditas em Niterói, o que corresponde ao período áureo dessa imigração para o Brasil. ${ }^{10}$

A grande questão que os números evocam, na verdade, é compreender o que esses 296 comerciantes significavam para a economia local. Se considerarmos que o censo de 1950 estimou a população de Niterói em 186.309 habitantes, e o percentual de população judaica não chega a 1\%, 
com base nos números projetados, tenderemos a desprezar a importância do grupo para a cidade. Porém, os mesmos indivíduos ganham destaque se considerarmos as precárias condições econômicas da capital fluminense e a força da presença imigrante no comércio local, sobretudo, portugueses e libaneses. ${ }^{11}$

No que se refere à compreensão do próprio grupo, os números indicam, a priori, um predomínio dos lojistas sobre os prestamistas na proporção de $60,8 \%$ e $39,2 \%$ respectivamente. Neste caso, é preciso chamar a atenção para as narrativas dos entrevistados sobre a relação, muitas vezes conflituosa entre esses dois lados. Boris Mocny, dentista, 73 anos, filho do alfaiate Sucher Mocny, e ativo militante da Biblioteca Davi Frishman/ ADAF, forneceu importantes declarações a respeito:

$\mathrm{Na}$ oficina de meu pai tinha 18 funcionários, era grande /.../. Pois bem, por essa época o prestamista chegava lá mandava um corte de fazenda, 'ah o Joaquim vem aí tirar as medidas pra fazer um terno pro casamento dele'. Faz o terno do casamento, normalmente entrava segunda era pra sábado, e sábado tinha o casamento. Ele chegava, colocava o terno, estava tudo bem, tudo certinho e embora. Aí o prestamista chegava depois e aí (quando meu pai perguntava pelo dinheiro), 'ainda não pagou a $1^{\mathrm{a}}$. Prestação', (disse meu pai) 'quê que eu tenho com isso, meus funcionários tem que receber no sábado, sábado eles tem que levar dinheiro pra casa, como é que fica?', 'Ah mas o que você quer que eu faça? Não tem milagre'. Aí quê que o velho fez (em outra oportunidade quando o mesmo prestamista solicitou um terno) Perfeitamente, sábado? Sábado está pronto. Sábado, o cara chegou lá pro casamento, 'Cadê o meu terno?', 'Que terno?', 'Ah, de fulano de tal', 'Ah sei, mas só com ele, só posso entregar a ele', Como', 'Não sei, vai na casa dele, o que você vai fazer não sei', aí ele foi lá, não encontrou ele em casa, tava na sinagoga, 'O cara não quer me entregar o terno, diz que só com você', ele veio, (incompreensível) ' $\mathrm{O}$ meu amigo, se você pagar eu entrego, os operários estão esperando o seu dinheiro para pagar a eles. Como é que fica?'. 'Mas não é justo, eu sou religioso'. Tudo bem, eles também são religiosos, só querem comer...' / .../ a maioria dos prestamistas que se viraram ganharam e roubaram muito, roubaram...compravam e não pagavam, eram especializados nisso, por isso que eles compravam a mercadoria por dois reais, chutar o dinheiro de hoje, vendia por quinze reais, recebia seis, se o cara não pagasse o resto, tudo bem...(ri) era assim minha filha. ${ }^{12}$

Como se pode verificar, a imagem do prestamista ladrão e mau pagador, de um lado, e a do lojista rico, por outro, povoam o imaginário do grupo na cidade, e a bem da verdade traduzem uma relação tensa entre os dois 
pólos de uma mesma moeda: os estabelecidos e os que desejavam se estabelecer.

De acordo com Helena Lewin ${ }^{13}$, diferente do lojista que era fixo e submetido a um conjunto de regularidades convencionadas pela legislação, a característica do clientelchik era a circulação por espaços distantes do centro da cidade, pela periferia.

Esse movimento implicava na difusão da novidade para um conjunto amplo de população, que passou a desfrutar da possibilidade de pagar os bens adquiridos em parcelas mensais, ou seja, a prestação. A atividade do prestamista incorporou ao mercado um conjunto amplo da população que esteve apartada dos sistemas de crédito oficiais no Brasil, durante boa parte do século XX.

Se o clienteltchik difundia a novidade, facilitava o acesso a bens raros, como no caso citado por Mocny, o sonhado terno do casamento, ele dependia da boa vontade do lojista para estender o crédito ao cliente, e assim concretizar a venda. O comerciante, por sua vez, era "uma figura estratégica como preditor de sucesso ou fracasso do clientelchtik" ${ }^{14}$ Cabia a ele decidir "o que vender, o quanto vender", e o prazo para o pagamento das mercadorias. Assim o clientelchik estava nas mãos do lojista.

Mais uma vez, entretanto, lembremos-nos do depoimento de Boris Mocny: se o prestamista não pagasse o alfaiate não haveria casamento, por conseguinte, o lojista também dependia do prestamista, mesmo que em menor grau.

Essa era uma relação, portanto, permeada pelo conflito. Se por um lado, havia complementaridade entre essas funções, que tanto podem ser entendidas como estratégias de solidariedade e dominação intragrupal, por outro lado, havia uma aura de tensão que perpassava essas relações, as diferenciava, e situava esses atores em campos opostos.

Os ruídos dessa dicotomia na coletividade de Niterói puderam ser ouvidos nas diversas entrevistas realizadas com membros do grupo, que apontaram a projeção para o universo institucional, de conflitos que nasceram no campo do trabalho. As questões político-ideológicas e institucionais da coletividade se confundiram muitas vezes com a luta de classes.

Helena Lewin assinala, ainda, que o conflito entre esses comerciantes reverberou, também, na quebra dos padrōes originais de atribuição de 
status promovido pela interação dos judeus na sociedade de acolhimento. Se nas diversas comunidades de origem, a cultura judaica valorizava "o conhecimento, o saber talmúdico, a linhagem familiar, o comportamento ético-religioso" como dados indispensáveis para o reconhecimento social de um indivíduo, na sociedade de acolhimento o que valia era pura e simplesmente a capacidade de fazer fortuna. ${ }^{15}$

Embora os dados apontem o predomínio do comércio de portas abertas sobre o trabalho do clienteltchik, chama atenção o fato de quase $83 \%$ dos indivíduos identificados como prestamistas terem se mantido enquanto tal. Em Niterói, o percentual de transferência de uma atividade para outra foi de apenas $17 \%$.

Esse reduzido percentual assinala outro dado importante, que vai em direção oposta à memória elaborada pelo grupo, a da transformação dos clientelchik em lojistas. O que em outras palavras sinaliza que, em Niterói, um índice alto de prestamistas manteve-se nesse ofício durante toda vida.

Abrir uma loja não foi uma conseqüência natural do capital acumulado pelo ambulante, e mesmo que na memória de muitos essa atividade fosse penosa, humilhante, era perfeitamente possível ganhar bastante dinheiro nessa função. A trajetória do palestino Isac Schor, uma dentre as várias histórias de prestamistas bem sucedidos em Niterói, ilumina essa questão.

Isac Schor nascido em Jerusalém no ano de 1889 , emigrou para o Brasil em 1912, aos 23 anos, deixando a mulher Bertha e dois filhos, José e Bernardo. Como a maioria dos imigrantes daquela época aportou no Rio de Janeiro, e residiu um tempo na capital federal, mudando-se depois para o outro lado da Guanabara, a fim de tentar a sorte "trabalhando com clientela". ${ }^{16}$

Em 1918, provavelmente após ter acumulado algum pecúlio, e ter sido assinado o armistício que encerrou a $1^{\mathrm{a}}$. Guerra Mundial, Schor retornou para a Palestina. Em Jerusalém, o ex-prestamista alugou casa para morar e montou uma mercearia na cidade velha.

Em 1920, porém, motivado pela perseguição dos árabes, "fustigados pelos ingleses", conforme narrou Judith Zoonisein, emigrou novamente para o Brasil, voltando a se estabelecer em Niterói, outra vez como prestamista. Desta feita, acompanhado da família. Ao longo da década de 1920, quatro novos filhos aumentaram sua estirpe, e os dois mais velhos, José e Bernardo, após terem feito o ginásio em boas escolas, como o tradicional colégio Pedro II, foram trabalhar com o pai. 
Em 1930, de acordo com a narrativa de Judith, Isac Schor adquiriu um palacete no centro da cidade. Em 1931, adquiriu um Chevrolet, que era utilizado para as visitas que fazia aos clientes. ${ }^{17}$

Segundo os manuscritos de Zoonisein, Isac Schor era um homem que gostava de viver bem, andava com boas roupas, e fazia frequentemente estação de águas com a mulher e as filhas, hábito comum entre a população abastada da época.

Em 1935, novamente Schor decidiu voltar para Jerusalém. Vendeu casa e carro, e embarcou de volta levando mulher, filhos, noras e netos. Em 1937, mais uma vez, e os motivos não ficaram claros, re-emigrou para o Brasil retornando para Niterói, onde refez sua clientela, ajudado pelos filhos. Em 1945, após longa doença, Isac Schor faleceu. Seus filhos continuaram a trabalhar como prestamistas por toda vida.

Vários pontos chamam a atenção na trajetória de Schor. Em primeiro lugar, o movimento de ir e vir, isto é, emigrar-reemigrar, o que ocorreu três vezes, entre 1912-1918; 1920-1935 e 1937. Praticamente inexistem no Brasil estudos sobre o movimento de retorno de emigrantes, ou sobre imigrantes sazonais. ${ }^{18}$

Oriundo da Palestina então sob dominação do Império Otomano, Schor viveu os derradeiros anos da dominação turca, e emigrou provavelmente junto à grande leva de "turcos" e libaneses que deixou a região entre 1890 e 1910.

Nos anos em que esteve trabalhando como prestamista em Niterói, a Grande Guerra esfacelou o império turco. Em 1917, Lord Balfour, Ministro das Relações Exteriores da Grã-Bretanha, prometia, em Londres, apoio britânico aos sionistas, para o estabelecimento de uma "pátria judaica na Palestina”.

Talvez estimulado por tantas transformaçōes, Schor tenha decidido retornar e tentar a vida na terra de origem. A realidade, no entanto, mostrou-se bastante diferente das promessas, e a família emigrou para o Brasil. Cerca de quinze anos depois, em 1935, em meio à onda crescente de antissemitismo que tomava conta do ocidente, às emigraçôes maciças de judeus para a Palestina, e os comícios virulentos dos integralistas de Niterói, a família Schor decidiu aventurar-se novamente na terra de origem.

Os manuscritos de Judith Zoonisein indicam um desejo de retorno definitivo, pois Schor vendeu todos os bens e carregou consigo filhos, 
noras e netos. Tratava-se, portanto, de fazer a vida na Palestina. Mas, alguma coisa deu errada, porque, menos de dois anos depois toda a família estava de volta.

Os livros de história narram a rebelião árabe contra as imigrações maciças que elevaram a população judaica de 50 mil habitantes nos anos vinte, para aproximadamente 300 mil judeus às vésperas da Segunda Guerra Mundial. ${ }^{19}$ Os Schor, provavelmente, ao tentarem se integrar naquela sociedade tiveram que lidar com uma disputa feroz por trabalho na região, assim como um contexto político-social dificílimo, que os anos de interação social no Brasil, particularmente na pacata Niterói, tornaram ainda mais insuportáveis.

De 1937 em diante, o contexto internacional tornou impossível o deslocamento pelo oceano, e ele teve que se aquietar em Niterói até falecer, em 1945, aos 56 anos.

É bem provável que a trajetória de Schor tenha sido diferente daquela que projetei nas linhas acima, porém, o contexto em que esteve inserido permite tal especulação. Em alguns aspectos, sua trajetória diverge bastante da maioria asquenaze que povoou Niterói naqueles anos, e que não tinha para onde voltar. ${ }^{20}$

Conforme evidenciado, havia uma maioria esmagadora de judeus do leste europeu na cidade, com os quais Schor e outros palestinos devem ter tido grande dificuldade de integração, dadas as diferenças culturais, étnicas, lingüísticas e religiosas entre eles. A atividade comercial, certamente, foi um meio privilegiado de integração desses indivíduos de diferentes tradições históricas, culturais e rituais. A disputa no mercado de trabalho, o recurso às instituições de auxílio na coletividade e a troca de solidariedades entre esses tipos diversos resultou numa nova forma de ser judeu, viabilizando suas vidas e a constituição de instituiçôes culturais e assistenciais na sociedade de acolhimento.

O segundo ponto a destacar no relato anotado por Zoonisein, foi a prosperidade alcançada por Schor, ao longo do período em que viveu em Niterói, e que tornou possíveis os deslocamentos transatlânticos da família, assim como montar casa e negócio na Palestina, comprar palacete e carro na capital fluminense, fazer estações de água, etc. Esse é um dado revelador de que o ofício de ambulante, embora árduo e às vezes mal compreendido, poderia ser bastante rentável e permitir condições de vida dignas aos seus praticantes. 
Os intervalos em que Isac Schor esteve na terra natal, pelo menos ao que tudo indica se não desmantelaram a clientela que formou durante os anos em Niterói, não o impediu de se re-colocar no mercado de trabalho da cidade, e acumular novo capital, dado que aponta as possibilidades do seu ofício no período e a capacidade do "mercado consumidor" local de absorver esse tipo de trabalhadores.

É, pois, o vigor da profissão de prestamista, sua importância para a clientela, que efetivamente se beneficiava das modernidades vendidas pelo ambulante, mesmo que fosse mercadoria barata, a "shmat", é que pode explicar as diversas re-inserções econômicas de Isac Schor no mercado de Niterói.

Se o sonho de todo prestamista era abrir uma loja como demonstrou o conjunto dos depoimentos e mesmo os diversos estudos que existem sobre o tema, a realidade em Niterói aponta características peculiares, interessantes para o estudo. Dos 140 prestamistas arrolados para o período, apenas 24 abriram lojas, o que pode ser sinal tanto da dificuldade para acumular capital, como das possibilidades que a clientela ensejava ao clientelchik, que, como no caso do citado Isac Schor, e outros tantos, garantiu prosperidade.

Um depoimento importante nesse sentido foi prestado pelo médico anestesista Jacó Lipster, atual presidente do Centro Israelita de Niterói. Filho e irmão de prestamista, Lipster atuou como tal enquanto estudava medicina no início da década de 1950, e, às vésperas de se formar, pensou em largar a profissão tão custosamente adquirida para continuar vendendo de porta em porta, porque, conforme asseverou, ganhava muito bem naquela atividade.

Além do Dr. Lipster, que já era nascido no Brasil, e pertencente à segunda geração, outro médico pagou os estudos à custa do trabalho como prestamista: Jankiel Stizberg.

Assim, ser prestamista poderia ser tanto um ofício para toda a vida, como trabalho temporário: preço pago para custear os estudos, ou a ponte para a abertura de uma loja. Em Niterói, foram poucos os casos anotados de filhos que herdaram a profissão do pai.

Um dos quadros que puderam ser elaborados a partir das listagens iniciais foi o perfil geracional da transmissão das ocupações. Vejamos. 
Quadro I. Judeus no Comércio: Perfil Geracional -1910-1970 21

\begin{tabular}{|l|c|c|c|c|}
\hline Geração & Prestamistas & Lojistas & Total & Total \% \\
\hline $1^{\text {a }}$ Geraçãao & 136 & 166 & 302 & $94,4 \%$ \\
\hline $2^{\text {a }}$. Geração & 4 & 13 & 17 & $5,6 \%$ \\
\hline
\end{tabular}

O quadro demonstra o predomínio absoluto da primeira geração no comércio das ruas e das lojas, e, por conseguinte, a baixíssima participação dos filhos nos negócios dos pais. Dos quatro prestamistas de segunda geração identificados, um formou-se em medicina, o já citado Jacó Lipster. Alberto Graber teve loja junto com o pai, Simão Graber. Sobre os demais, David Taitelboin e Herman Tiber, nada foi possível apurar. ${ }^{22}$

É importante analisar o caso de Alberto Graber. Seu pai, Simão, morto aos 104 anos, em 2004, foi uma figura lendária no comércio de Niterói. Do primeiro crédito à charrete, e trabalhando do amanhecer ao entardecer, sem pausa para almoço, Graber galgou posição de destaque na coletividade. Em apenas uma década de Brasil, pois chegou em 1932, já era considerado um prestamista bem sucedido, tinha condução própria e circulava pela cidade com uma charrete, estando alguns degraus acima de outros clienteltchik.

Somente na década de 1960 é que Simão Graber abriu sua primeira loja, cujas portas ainda estão abertas na cidade. Coroamento da trajetória de prestamista? Sinal dos novos padrões de status incorporados pelos judeus no Brasil? Todas as hipóteses são válidas, mas ao lado delas, outra questão deve ser aventada. Graber formou apenas um dos três filhos que teve: o arquiteto Júlio Graber. Os outros dois, Alberto e Edna, não quiseram estudar. Mesmo que Edna se casasse e esse era o destino esperado para as mulheres, havia Alberto e ele precisava de trabalho.

A Gabier Presentes, portanto, surgiu simultaneamente como realização e solução para os sonhos e problemas do antigo prestamista: o prestígio de ter uma loja e garantir trabalho para os filhos, sem grandes perspectivas profissionais. A loja chegou a ter quatro filiais entre Niterói e Rio de Janeiro.

Alguns depoentes explicaram a presença da segunda geração no comércio, como fruto de situações similares à vivida por Graber. A grande maioria da segunda geração, no entanto, dentro do que lhes foi possível escolher, fizeram opções bem diferentes dos filhos de Graber ou 
de Isac Schor, que viveram e morreram abraçados ao ofício herdado dos pais. Diferenciaram-se deles, com diploma universitário e colação de grau. ${ }^{23}$

Simão Graber, como vimos, vendia de porta em porta a bordo de uma charrete, fato que os distinguia dos demais. Afinal, numa profissão em que era fundamental percorrer muitos quilômetros, ser ágil era um dos atributos mais importantes. Assim, ter meio próprio de transporte se tornava um investimento importante para quem pretendesse ser bem sucedido. Eram poucos os prestamistas que desfrutavam dessa condição.

Antes, porém, de sonhar com um meio de locomoção próprio, dependendo das condiçóes em que chegava o imigrante, ele poderia começar simplesmente acompanhando um prestamista mais experiente na profissão para aprender como fazer e o que falar. A segunda etapa consistia em comprar a freguesia de outro prestamista e ampliá-la. Uma clientela considerada boa deveria constar de 150 a 200 cartões. $^{24}$

Paulo Velmovitsky, em seu depoimento explicou como se dava o processo:

Chegava um camarada da Europa, pedia crédito. Ele era chamado de griner (verde não está maduro). Eles apanhavam o crédito e compravam a mercadoria e muitos deles usavam métodos... (próprios). Meu tio, Jacó, por exemplo, ele se plantava na Praça Mauá, de macacão de operário e fingia que tinha acabado de sair do navio. Ele ficava na Praça Mauá fingindo... - -isso ele me contou (risos). Trazia uns dois, três cortes de fazenda e dizia — 'Eu vou embora, vendo por qualquer preço, eu quero ir embora daqui...' $\mathrm{E}$ com isso ganhava seu dinheirinho.

Meu pai, por exemplo, ia com esses pobretóes, uns rapazes muito pobres, que carregavam (para ele) uma mala cheia de fazendas, não sei como eles agüentavam tanto peso. Ia meu pai na frente e o carregador atrás. Quando eles se aproximavam de um imóvel, para ver se vendiam mercadoria, ela (a dona de casa) já sabia que era (o vendedor) a prestação e não abriam a porta, aí ele batia à porta e elas diziam - 'Vai embora, Vai embora', — 'Tá bem, eu vou embora, mas me dá um copo de água pelo amor de Deus, eu estou com sede' e recebia o copo de água. Eles ficavam conversando para passar a conversa na dona. ${ }^{25}$

A par das dificuldades, o cotidiano de um prestamista exigia planejamento. De acordo com Ilse Sipres, cujo marido Moisés, pedalou quarenta anos pelas ruas de Niterói, o dia de trabalho de um prestamista começava por volta das 8:00 horas da manhã e terminava entre 16:00/ 17:00 horas. Nesse período almoçava uma fruta em alguma quitanda no 
caminho. Depois de pedalar por diversos bairros, retornava ao lar, onde jantava. À noite, separava os cartões para o dia seguinte, quando ordenava o roteiro a seguir e dividia matematicamente o tempo entre as visitas à clientela e as idas ao Rio de Janeiro, onde comprava mercadorias, o que ocorria pelo menos duas vezes por semana. Finalmente fazia a contabilidade.

A semana de trabalho para Moisés tinha seis dias, de segunda a sábado. Aos domingos assistia a concertos no Teatro Municipal do Rio de Janeiro. Embora oriundo de uma família muito religiosa, assim como a jovem esposa, Sipres não guardava os sábados. Posteriormente se converteu num judeu ortodoxo aberto, conforme qualificado pela senhora.

Segundo Ilse, não havia entre os prestamistas uma especialização por bairros. A vasta clientela do marido, por exemplo, estava espalhada pela cidade. Vendia basicamente cortes de tecidos, casacos, ternos, colchas, enxovais completos para noivas e móveis. Jóias, apenas quando pediam.

Quanto aos móveis e roupas de alfaiataria, o cliente pedia a indicação da loja e o clienteltchik ganhava comissão. No caso de ternos, conforme o depoimento de Boris Mocny demonstrou, o pagamento pela roupa era feita diretamente ao prestamista que retirava seu lucro e repassava a parcela do alfaiate. Assim, os mundos das ruas e das calçadas se interligavam.

Aposentado desde o início da década de 1980 e falecido em 1988, a figura de Sipres ou Seu Maurício, como era chamado por sua clientela, marcou a vida de muitos de seus clientes, que não deixaram de comparecer ao seu enterro no cemitério do Centro Israelita de Niterói. ${ }^{26}$

De acordo com Lewin o clienteltchik cumpriu a função de ligar mundos distintos, o da economia tradicional dos setores populares à economia capitalista moderna, por intermédio de uma relação baseada na confiança simbólica. ${ }^{27}$

Para esses grupos sociais era o prestamista quem fazia essa transição, e o meio pelo qual o realizava era o do estabelecimento de uma relação pessoal, baseada na confiança e na palavra. O clienteltchik não apenas batia palmas, era convidado a entrar e tomar cafezinho, "jogar conversa fora”: penetrava na vida das pessoas, quase sempre mulheres. O prestamista traz o mercado "para o espaço privado onde quem domina é a mulher". ${ }^{28}$ Ao adentrar as casas, este profissional acabava por se embrenhar nos jogos secretos das famílias: "ouvir sem falar tornou-se a regra de ouro para sua permanente aceitação pela freguesia". ${ }^{29}$ 
Uma história interessante e que marca bem a relação estreita entre o clienteltchik e a clientela, e a importância social que este adquire para o cliente, pode ser apreendida na seguinte passagem da carreira de Seu Maurício ou Moisés Sipres, narrada por sua viúva.

O fato ocorreu numa véspera de Yon Kippur, o dia do perdão para os judeus. Sipres havia combinado chegar mais cedo para celebrar a data com a família. Na véspera, havia, como de hábito, selecionado os cartões da clientela de Jurujuba, uma colônia de pescadores nas margens da Baía de Guanabara. Pela manhã, como planejado, foi vender naquele lugar. Naquele dia ele se esquecera de levar a licença e acabou preso em pleno Yon Kippur. Levado para a delegacia, foi mandado para o xadrez. A notícia se espalhou por Jurujuba: "prenderam Seu Maurício!" Clientes amigos foram falar com o padre, que mandou tocarem os sinos para avisar que "prenderam Seu Maurício". A clientela em peso foi para a delegacia para "soltar Seu Maurício"! 30

Essa história que mais parece um conto é verídica e demonstra como o prestamista se incorporou àquela geografia e ao cotidiano da população. Evidente que nem todos alcançaram esse prestígio junto à clientela.

O trabalho como clienteltchik foi o meio possível de integração para pessoas que emigraram em situações arriscadas, ou de extrema pobreza. Muitos desses indivíduos trouxeram de sua terra natal uma bagagem cultural enorme, grande experiência política, e algumas, mesmo sem ter alcançado expressão econômica, obtiveram prestígio dentro da coletividade pelo seu elevado saber. O próprio Simão Graber havia sido presidente de sindicato em Varsóvia, e continuou um militante de esquerda no Brasil, além de comerciante bem sucedido. A História da coletividade de Niterói, assim como outras, está cheia desses casos.

Há ainda outro aspecto a ser abordado: o crédito, as associações de auxílio e a contabilidade. A concessão do crédito era fundamental para o início da vida do prestamista, o que poderia ser obtido de particulares ou de alguma associação de ajuda mútua. Na capital federal desde 1916, a comunidade judaica da Praça XI, organizou inúmeras entidades de auxílio financeiro aos imigrantes, como o Achiezer (ajuda ao irmão), posteriormente Sociedade Beneficente Israelita e Amparo aos Imigrantes, o Relief, a União dos Prestamistas, e várias caixas de empréstimos. ${ }^{31}$

Em Niterói, vários comerciantes estabelecidos concediam créditos aos recém-chegados. A cessão do crédito, é importante que se diga, não era 
apenas uma forma de solidariedade, mas também de ganhar dinheiro e prestígio dentro da comunidade. Calcula-se que os negociantes que se estabeleceram com loja, ainda nas décadas de 1910 e 1920, como os irmãos Isac e Germano Treiger, (1911), Jacob Tubenchlak, (1915), Hanô Lent, Isaac Chapiro, os irmãos Baron, Luiz e Henrique Pochachevisky, Nicolas Ferges, Adolfo e Jacob Schwartz, Júlio Soichet, J. Teicher, entre outros, tenham reproduzido a prática dos seus contemporâneos da Praça XI. ${ }^{32}$

No que se refere às associações de crédito e de prestamistas, tudo indica que a citada União dos Ambulantes de Niterói, fundada em novembro de 1940 , tenha sido a institucionalização de uma organização informal que existia desde o final da década de 1910 ou 1920. De acordo com Paulo Velmovitsky e Jacó Kosman, foi formalizada, sobretudo, para salvaguardar os direitos dos prestamistas, e resguardá-los das razias promovidas pelos fiscais que caíam em cima dos ambulantes. Vale dizer que a fiscalização da Prefeitura de Niterói era intensa e segundo alguns tinha uma inclinação anti-semita. ${ }^{33}$

As origens da UBAN, entretanto, remetem a um conjunto de dúvidas, das quais não trataremos neste artigo e que se referem a questões políticas e ideológicas da comunidade de Niterói. ${ }^{34}$ Já a Entidade dos Ambulantes Judeus que funcionou na sede da Biblioteca Davi Frischman nas décadas de 1950-60, tinha à frente os prestamistas Luíz Kerchberg, Luiz Szemberg e Wolf Cukier. Outra associação de auxílio foi a Caixa de Ajuda Rachel Gueller, dirigida por Marcos Gueller e também datada dos anos cinqüenta.

Sobre a Entidade dos Ambulantes Judeus, frequentemente confundida com a UBAN, tratava-se de uma associação formal, registrada em cartório que objetivava dar guarita legal aos ambulantes constantemente acossados pela fiscalização.

Conforme explicaram, os prestamistas compravam suas mercadorias em consignação, sem nota fiscal. No ínterim entre a compra, a venda e a devolução, a fiscalização da Prefeitura exigia as notas fiscais. O resultado era a apreensão da mercadoria, e, às vezes, a prisão do ambulante como contrabandista, sobretudo dos que trabalhavam com ouro. Na tentativa de solucionar o problema, e, de quebra, driblar a cobrança de impostos, os prestamistas passaram a comprar os artigos em nome da associação. A nota fiscal saía em nome da entidade, e o imposto era rateado por todos ${ }^{35}$.

Sobre a Caixa de Ajuda Rachel Gueller pouco se sabe. Graças ao depoimento de Judith Zoonisein, que guardou a caderneta do marido, foi 
possível redescobrir sua existência, porém, não alcançamos detalhes sobre seu funcionamento.

Se Moisés Sipres era bem quisto pela clientela, outros prestamistas amargavam realidade diversa. Luís Baunfeld se recorda do pai chegar a casa com lágrimas nos olhos, tanto por causa das pessoas que se recusavam a pagar, como pelos xingamentos que ouvia dos maus pagadores: judeu, filho...!

A propósito da inadimplência, a contabilidade de um prestamista era um assunto delicado, seu sucesso dependia do controle rigoroso, por um lado, das contas da família, e de outro, da administração dos prazos nos dois pólos da sua ação, isto é, os largos prazos para pagamento concedidos pelos lojistas e os oferecidos para os fregueses ${ }^{36}$.

No tocante à composição sexual, o mundo dos prestamistas e dos lojistas, ao menos em Niterói, era predominantemente masculino, como se pode observar no quadro abaixo:

Quadro II - Composição Sexual

\begin{tabular}{|l|l|c|c|c|}
\hline & $\begin{array}{l}\text { Prestamistas } \\
(116)\end{array}$ & $\%$ & $\begin{array}{c}\text { Lojistas } \\
(180)\end{array}$ & $\%$ \\
\hline Mulheres & 7 & $6 \%$ & 16 & $9 \%$ \\
\hline Homens & 109 & $94 \%$ & 164 & $91 \%$ \\
\hline $\begin{array}{l}\text { Total Geral Feminino } \\
\text { Percentual Feminino }\end{array}$ & 23 & & \\
\hline Total Geral Masculino & $7,7 \%$ & & & \\
Percentual Masculino & $92,3 \%$ & & \\
\hline
\end{tabular}

No caso do trabalho ambulante, apenas 6\% do total arrolado era composto por mulheres e todas se referem à senhoras que deixaram o espaço doméstico após a década de 1950, dentre elas constavam três viúvas. Neste caso, é a própria condição de viuvez que justifica a entrada em um mercado de trabalho masculino.

Outras mulheres como Leia Naiman, Rachel Cremer e Zilda Michmacher entraram no mercado para ajudar os maridos num tempo que era incomum, no contexto específico da cidade de Niterói, as mulheres trabalharem, a não ser nos casos das lavadeiras, costureiras, passadeiras e bordadeiras, muitas de origem portuguesa e que quase sempre o faziam no âmbito das suas casas. ${ }^{37}$ 
Diferente das imigrantes de origem judaica instaladas na capital federal, as judias em Niterói, até a década de 1950, raramente trabalhavam fora de casa. Suas filhas, no entanto, já na década de 1940 começaram a atuar no mercado de trabalho como funcionárias públicas como foi o caso de Ássia Lempert, ou como professoras, como Judith Zoonisein.

Para as gerações pioneiras era preciso coragem para romper com os padrōes impostos pela cultura de origem. ${ }^{38}$ Este foi o caso de Zilda Michmacher e Sara Rabinovici, que "arregaçaram as mangas" para ajudar os maridos a contornarem situações econômicas difíceis.

A coletividade israelita, de modo diverso a outros grupos de imigrantes dedicou-se de forma incomum às suas organizações sociais. Não há paralelo com outras sociedades imigrantes, mesmo com os portugueses, multiplicados pelas inúmeras casas regionais ${ }^{39}$.

Muito embora todos estivessem comprometidos em fazer a América, no sentido mais estrito de ganhar dinheiro, para diversos tipos de judeus fazer a América significava, também, fincar raízes, estabelecer novos laços comunitários, uma junção de ações que aparentemente parecem contraditórias, qual sejam: conquistar o país, tanto pela via do trabalho, como pela demarcação da sua diferença. $\mathrm{O}$ meio que empregaram para tal foi a aplicação de seu tempo livre na constituição de uma intensa vida institucional. Assim à ideologia do trabalho ${ }^{40}$ se somou o ideal comunitário.

A presença judaica no comércio varejista de Niterói era realidade desde 1911, quando Isaac Treiger abriu sua primeira loja na cidade, a Casa Confiança, escavando um nicho em que a presença judaica se tornaria tradição: o ramo do mobiliário. $\mathrm{O}$ quadro abaixo assinala as áreas de concentração do comércio lojista judeu. 
Quadro III - Presença Judaica no Comércio de Niterói -1910-1970

\begin{tabular}{|l|c|c|}
\hline RAMOS & Total de Lojas & $\%$ \\
\hline Alfaiataria & 31 & $\mathbf{1 6 \%}$ \\
\hline Movelaria & 45 & $23,3 \%$ \\
\hline Colchoaria & 5 & $2,5 \%$ \\
\hline $\begin{array}{l}\text { Armarinhos/Bazares/ Tecidos/ } \\
\text { Belchiores (ferro-velho) }\end{array}$ & 11 & $5,7 \%$ \\
\hline Fotografia/Pintura & 4 & $2,2 \%$ \\
\hline Calçados & 11 & $5,7 \%$ \\
\hline Moda/Roupa Pronta & 23 & $12 \%$ \\
\hline Joalheria/Relojoaria & 25 & $13 \%$ \\
\hline Eletro/Material de Construção & 6 & $3,3 \%$ \\
\hline Imobiliária/Construção Civil & 3 & $1,6 \%$ \\
\hline Chapelaria/sombrinhas/Malas & 8 & $4,3 \%$ \\
\hline Diversos & 19 & $10,4 \%$ \\
\hline \multicolumn{1}{|c|}{ Total de Lojas } & 193 & $100 \%$ \\
\hline
\end{tabular}

Os dados acima assinalam de forma inconteste a concentração dos imigrantes judeus nos ramos do vestuário, mobiliário e joalheria, que somados representaram $\mathbf{6 4 \%}$ das lojas abertas por imigrantes judeus no período analisado. A explicação para a preferência por esses setores pode estar na experiência acumulada na sociedade de origem, pois, os "judeus estavam relativamente urbanizados e concentravam-se em ocupaçôes relacionadas às manufaturas e ao comércio". ${ }^{41}$

Ademais, um percentual bastante elevado "desses judeus urbanizados" eram portadores de profissão, segundo o próprio autor. Esse foi o caso, por exemplo, do pai de nosso depoente Boris Mocny, Sucher Mocny, que emigrou para o Brasil em 1929.

Não há dúvida que com profissão definida ou alguma habilidade particular a vida ficava mais fácil. No caso de Sucher, o estabelecimento que abriu em 1931, a Alfaiataria Internacional foi a mesma loja que manteve até sua aposentadoria e com a qual formou os dois filhos em odontologia e construiu algumas casas para alugar. Sucher, que morreu aos 96 anos, passou a velhice desfrutando do patrimônio que construiu, isto porque, como lembrou o filho, a alfaiataria: "Dava, dava dinheiro, não /.../ bater de porta em porta pra vender panela, não precisava, ele era profissional. Ele tinha poder aquisitivo".

Em Niterói, na primeira metade do século XX, boa parte do comércio varejista do centro, o principal lócus econômico da cidade, era parcialmente ocupado por armarinhos de tecidos e alfaiatarias, de imigrantes síriolibaneses, judeus, italianos e portugueses, que protagonizaram enorme 
disputa pelo mercado consumidor. Porém foi na venda de móveis prontos que os judeus mais se destacaram. Vejamos brevemente as trajetórias de Isaac Treiger e Jacó Tubenchlak, este pai da depoente Judith Zoonisein.

Os Treiger, oriundos de Secureni, na Bessarábia, então sob domínio russo, desembarcaram no Rio de Janeiro em 1911, se estabelecendo diretamente em Niterói. Nesse mesmo ano, o filho Isaac abriu a Casa de Móveis Confiança. Em 1915, a propaganda da loja já constava das páginas do Almanak Laemmert. O ano de 1919 trouxe a concorrência das lojas de Jacó Tubenchlak, Casa Progresso, (depois Mobiliadora Progresso), e dos irmãos Fernando e Moisés Baron, a Casa Baron. Finalmente no ano de 1924, a loja de Isaac Treiger reaparece, desta feita como mobiliadora e colchoaria, e como sociedade entre os irmãos, Isaac e Germano, que mais tarde também incluiriam um açougue ao rol dos seus negócios.

Treiger e Tubenchlak protagonizaram um duelo a parte em Niterói, conforme relatado pela filha deste, Judith Zoonisein. Diferente do rival, que já entrou no mercado como lojista, Tubenchlak galgou o caminho inicialmente como prestamista.

Natural de Chagarov, na Rússia, Tubenchlak chegou por volta de 1912 a Niterói, onde trabalhou inicialmente como clienteltchik, e depois empregado na loja de móveis de Isaac Treiger. Em 1916, segundo a filha, já estava inscrito como lojista na Associação Comercial de Niterói, dono da Casa Progresso, três anos mais tarde Mobiliadora Progresso.

Enquanto a Mobiliadora Progresso, era símbolo de elegância e espaço de sociabilidade para imigrantes judeus que à noite se reuniam para ouvir a leitura dos jornais brasileiros pelo proprietário, a Casa Confiança, de Treiger, revendia móveis populares a preços módicos. Enquanto Tubenchlak dedicou toda a vida à sua loja, os irmãos Treiger diversificaram o negócio original.

Tanto Treiger como Tubenchlak estavam inseridos no mercado em um ramo - o mobiliário, que concentrou quase $24 \%$ dos comerciantes judeus no período, ou seja, 1/4 do total, reunidos ao longo das principais ruas do centro de Niterói - Avenida Visconde de Rio Branco e da Rua Marechal Deodoro, esta última, ainda hoje caracterizada pelo comércio de móveis. Ao contrário do ramo da alfaiataria e das roupas prontas em que dividiram com "sírio-libaneses" o espaço no mercado, a movelaria foi um lugar quase exclusivo dos judeus em Niterói.

Da mesma forma, o comércio do ouro foi outro lugar judeu na cidade, mas ao menos este pode ser explicado pelas diversas levas de judeus que 
desembarcaram trazendo no bolso essa credencial: ou porque estavam inseridos na dinâmica do comércio de diamantes dirigido de Amsterdã, na Holanda, para a Europa, ou porque tiveram contato com estes ${ }^{42}$. O fato é que assim como no caso do mobiliário, outros $13,2 \%$ da parte economicamente ativa da coletividade dedicaram-se a venda de jóias, além do que uma parcela grande dos prestamistas também revendia jóias, sendo por isso, tão visados pela fiscalização.

No universo das lojas tal qual na atividade das ruas, a predominância masculina também era uma realidade: $92,3 \%$ dos comerciantes identificados eram homens, porém, é provável que contassem com o apoio das mulheres nos balcões.

Paralelamente ao comércio, os imigrantes judeus tiveram grande participação na edificação do equipamento urbano residencial da cidade, desde a construção civil de pequena monta aos pequenos e grandes edifícios do bairro de Icaraí, que foram erguidos a partir dos anos cinqüenta/ sessenta em diante. Este foi o caso, por exemplo, da Construtora Wrobel, dos irmãos Samuel, Jacó, Moisés e José, poloneses, nenhum deles engenheiro, e todos sócios de uma alfaiataria.

De acordo com a psicanalista Vera Wrobel, 60 anos, filha de Samuel, o mais velho dos rapazes, a construtora surgiu por um acaso, em meados dos anos cinquenta. Samuel e Jacó haviam emprestado dinheiro para um conhecido, que na impossibilidade de pagar em espécie ofereceu um terreno à Rua Gavião Peixoto, no bairro de Icaraí, como parte do pagamento. Sem grandes conhecimentos, e tendo como referência a experiência de outros membros da coletividade, os irmãos aceitaram o desafio e resolveram construir um pequeno prédio. O sucesso do empreendimento acendeu o desejo de prosseguir. Com o lucro obtido compraram outro terreno e assim sucessivamente.

Quem hoje se dispuser a andar ao longo da Rua Gavião Peixoto, que é uma das principais artérias do bairro de Icaraí, poderá identificar nos quarteirões entre as Ruas Otávio Carneiro e Mariz e Barros, uma série de prédios de quatro pavimentos, oito apartamentos por andar, similares entre si, sem garagem e caracterizados pela mais absoluta simplicidade. Todos levam a assinatura da Construtora Wrobel nos seus primórdios. ${ }^{43}$

A construção civil, portanto, representou outra forma de inserção no mercado que garantiu principalmente para a geração dos pioneiros, a de lojistas e prestamistas, uma forma de aplicação da poupança acumulada 
com vistas a garantir o futuro. Alguns de seus filhos, no entanto, beneficiados pelo status universitário transformaram a pequena atividade de construir uma casa para alugar, em um mega empreendimento imobiliário. Este foi o caso da Construtora Pinto de Almeida e da extinta Construtora Orcal. ${ }^{44}$

\section{Considerações Finais}

Para a geração que se estabeleceu na capital fluminense na primeira metade do século XX, o comércio dos lojistas e prestamistas foi o grande meio de inserção social e de conquista de cidadania. Vale registrar que, se as estratégias de integração econômica do grupo, na sua primeira geração se assemelharam a de seus congêneres e até mesmo a de outros grupos emigrados, os israelitas de Niterói conferiram um sentido de dominio próprio a esse setor, tanto pelas marcas que deixaram como pela simbologia que imprimiram no espaço da cidade. Ademais, garantiu-lhes a demarcação de diferenças em relação à realidade dos judeus estabelecidos na capital federal.

Merece destaque as características particulares que o trabalho de prestamista assumiu na antiga capital fluminense - o fato de $83 \%$ dos judeus que começaram seus dias trabalhando como clientelchik terem permanecido nesse ofício por toda a vida. Esse dado é importante para relativizar ao menos em Niterói, a crença de que o trabalho como prestamista foi mera ponte para o comércio lojista.

Finalmente, ao examinar e entrecruzar fontes das mais diversas origens e confrontá-las com a memória que a coletividade elaborou sobre sua experiência na cidade, acredito ter sido possível avançar no conhecimento das formas de dominio econômico, cultural e simbólico que foram praticadas pelo grupo no espaço da capital fluminense.

\section{Notas e Referências}

1 Rogério HAESBAERT. O Mito da Desterritorialização: do 'fim dos territórios' à multiterritorilidade. Rio de Janeiro: Bertrand Brasil, 2004.

2 É mister explicar que boa parte dos judeus que radicaram-se na cidade entre 1910-1980, autoproclamavam-se pertencentes a um grupo, a coletividadel comunidade judaica de Niterói, dotada de instituições próprias como a Biblioteca Davi Frischman (1922), Centro Israelita de Niterói (1925), a Sociedade Hebraica de Niterói (1962), e a Associação Davi Frischman de Cultura e Recreação (1967). É importante deixar claro que nem todos os judeus que se estabeleceram 
em Niterói no mesmo período, compartilharam dessa identificação, e nem mesmo atuaram nessas entidades.

3 Prestamista, mascate e clienteltchik são termos sinonímicos. Indicam o trabalho de vender objetos de casa em casa, sob a forma de prestações mensais. No caso dos judeus a figura do clienteltchiké muito popular.

4 Para tanto recorri à pesquisa em anuários e guias sobre Niterói, publicados entre 1910-1970, assim como ao Almanak Laemmert, entre 1910-1944, seu último ano de publicação. Os dados que emergiram dessas fontes foram cruzados com documentos oriundos dos arquivos das associaçôes judaicas da cidade e depoimentos de integrantes da comunidade local. Importa dizer que não foi possível compulsar a documentação da Prefeitura Municipal da cidade, tampouco da Associação Comercial, uma vez que eles se perderam.

5 Vale dizer que a publicação nesse prestigioso Almanak era paga, por conseguinte, poderia ser maior o número de judeus proprietários de lojas, gente que não pode ou não quis por motivos vários constar dessa publicação.

6 Para consultar os dados completos da pesquisa, nomes, endereços e tabelas ver Andréa CÔRTE. Os Judeus em Niterói: imigração, cidade e memória. 19101980. Niterói, PPGH-UFF: Tese de Doutorado, 2009, capítulo 4.

7 Trata-se de um grupo de senhoras que se reúnem todos os domingos na ADAF para almoçar e ensaiar o coral, quase todas na faixa entre 75/85 anos. Fora da ADAF contei com a colaboração de D. Ilse Sipres.

8 Jeffrey LESSER. O Brasile a Questão Judaica: imigração, diplomacia e preconceito. Rio de Janeiro: Imago, 1995, p. 315.

9 As estatísticas de nacionalidades resultaram do cruzamento das fontes orais com o referido livro da UBAN. Para ter acesso à tabela remeto ao leitor ao cap. $4 \mathrm{da}$ minha tese de doutorado In A. CÔRTE, Op. cit.

10 J. LESSER. Op. cit., pp. 44- 60.

11 Andréa CÔRTE. Op. cit.

12 Entrevista de Boris Mocny à autora, maio de 2007.

13 Helena LEWIN. A Economia Errante: a inserção dos imigrantes judeus no processo produtivo brasileiro. Separatum. Judaica latinoamericana. Estudios Histórico-Sociales III, Jerusalém, 1997, p. 401.

14 Id. ibidem, p. 401.

15 Id. ibidem, p.90.

16 Entrevista de Judith Zoonisein à autora, agosto de 2005; Manuscritos de Judith Zoonisein sobre a trajetória de Isac Schor.

17 Até 1950/60, a região central de Niterói combinou simultaneamente os espaços econômicos, políticos e residenciais, sendo lugar de moradia de banqueiros, grandes atacadistas, políticos, e pessoas pobres, situação que começou a mudar paulatinamente a partir dessas décadas. 

Estudo da Imigração Subsidiada para o Brasil”. In: Fernando de SOUZA e Ismênia MARTINS. Emigração Portuguesa para o Brasil. Porto: Cepesel Afrontamentos, 2007. Caso. 1930-1990. Nite. em Niterói. Op. cit., cap. 7.

Enciclopédia do Mundo Contemporâneo. São Paulo: Publifolha; Rio de Janeiro: Editora Terceiro Milênio, 1999, p.455.

J. LESSER. Op. cit., p. 45.

Este caso não exclui as repetições considerando o total de 140 prestamistas.

Para maiores dados ver A.CORTE. Op. cit., cap. 4

Para uma análise da 2a geração dos judeus em Niterói ver idem.

Entrevista de Paulo Velmovitsky à autora, 25 de setembro de 2006; Entrevista de Ilsa Sipres à autora, 14 de fevereiro de 2008. Helena Lewin, também aponta o quantitativo de cartôes comentado por Velmovitsky como representativa de uma boa clientela. H. LEWIN. Op. cit.

Entrevista de Paulo Velmovitsky à autora em 25 de setembro de 2006.

Entrevista de Ilse Sipres à autora, março de 2006 e fevereiro de 2008.

H. LEWIN. Op.cit., p.85.

Idem, p.92.

Idem.

Entrevista de Ilse Sipres à autora, 14 de fevereiro de 2008.

Samuel. MALAMUD. Recordando a Praça Onze. Rio de Janeiro: Kosmos Ed., 1988.

Entrevistas respectivas de Zilda Michmacher, maio de 2005; Judith Zoonisein, agosto de 2005; Regina Broitman, maio de 2007 à autora; Entrevista de Simão Graber à Rolande Fischberg In Boletim Informativo ADAF, julho/agosto 2003, p.6.

Depoimentos de Paulo Velmovitsky, 25 de setembro de 2006; Luís Baunfeld, novembro de 2006; As informaçōes prestadas por Jacó Kosman foram colhidas por Rolande Fischberg, em 2006.

Ver A. CÔRTE. Os Judeus em Niterói. Op. cit., cap.4.

Entrevista de Rolande Fischberg à autora, 14 de fevereiro de 2008.

H. LEWIN. Op.cit., p.86.

Andréa Telo da CÔRTE. A Imigração Madeirense em Niterói. Um Estudo de Caso. 1930-1990. Niterói, PPGH-UFF: Dissertação de Mestrado, Niterói,

Para uma discussão detalhada da vida associativa do grupo, ver Idem, cap.6.

José de Souza MARTINS. O Cativeiro da Terra. São Paulo: Hucitec, 1981, p.47. 


\section{Dôssie Imigração}

41 J. LESSER, 1995. Op. cit., p.67.

42 Saádio LOZINSKY. Memórias da Imigração. Rio de Janeiro: Ed. Garamond, 1997.

43 Entrevista de Vera Wrobel à autora, agosto de 2007.

44 A Construtora Pinto de Almeida, ainda em atividade e bastante próspera, contou com outros sócios não judeus. 